\title{
High blood pressure - an essential aspect in the family doctor practice
}

\author{
Cristina-Gabriela MILITARU ${ }^{1}$, Gabriel Cristian BEJAN², Ioana Veronica GRAJDEANU², \\ Oana NICOLESCU ${ }^{2}$, Anca Angela SIMIONESCU ${ }^{3,4}$, Ana Maria Alexandra STANESCU² \\ ${ }^{1}$ Pneumoftiziology Hospital, Campulung, Romania \\ ${ }^{2}$ Department of Family Medicine, "Carol Davila" University of Medicine and Pharmacy, Bucharest, Romania \\ ${ }^{3}$ Department of Obstetrics and Gynecology, \\ "Carol Davila" University of Medicine and Pharmacy, Bucharest, Romania \\ ${ }^{4}$ Filantropia Clinical Hospital, Bucharest, Romania
}

\begin{abstract}
High blood pressure (HBP) is the most common condition seen in primary care and leads to myocardial infarction, stroke, kidney failure and death if not detected early and treated adequately. Patients want to ensure that blood pressure treatment will reduce the disease burden, while clinicians want guidance for the management of high blood pressure using the best scientific evidence. High blood pressure is a global problem. The family doctor plays a significant role in prevention, early detection but also in monitoring the treatment. Current studies highlight the importance and need for family doctor involvement.
\end{abstract}

Keywords: high blood pressure, primary care, family doctor

\section{INTRODUCTION}

High blood pressure (HBP) is the most common condition seen in primary care and leads to myocardial infarction, stroke, kidney failure and death if not detected early and treated adequately. Patients want to ensure that blood pressure treatment will reduce the disease burden, while clinicians want guidance for the management of high blood pressure using the best scientific evidence. This report has a rigorous, evidence-based approach to recommending treatment thresholds, targets, and drugs to treat high blood pressure in adults. Evidence was extracted from randomized controlled trials, which are the gold standard for determining efficacy (1).

Comparable limited data are available on the prevalence of hypertension and temporal trends in blood pressure values in different European countries. In general, the prevalence of hypertension seems to amount to $30-45 \%$ of the general population, with a significant increase in patients' number. It also appears that there are visible differences in average blood pressure levels between countries, with no systematic trends in blood pressure changes over the past decade (2).

Globally, the prevalence of hypertension is around 1 billion people, according to the WHO, which is the leading cause of death due to its consequences (3). The control of blood pressure values must be improved because, at present, it is insufficiently achieved, thus contributing to an increased level of cardiovascular morbidity and mortality (4). The SEPHAR study showed a prevalence of hypertension of $40.1 \%$ in Romania, i.e. approximately 8.8 million hypertensives (5). 


\section{ESSENTIAL ASPECTS OF DIAGNOSING HYPERTENSION IN FAMILY MEDICINE}

For a correct diagnosis of hypertension, it is essential to use an appropriate blood pressure measurement technique. Improper blood pressure measurement is common and can change your blood pressure reading by up to $10 \mathrm{mmHg}$, leading to misdiagnosis and classification of hypertension.

Correct blood pressure measurement requires that the person whose blood pressure is to be measured be kept quiet for at least five minutes, followed by applying a blood pressure cuff adequately fitted to the empty upper limb. The person whose blood pressure is being measured should avoid talking or moving during this process. The measuring arm must be supported on a flat surface at the heart level (6). The bladder should be emptied before measuring a person's blood pressure, as it can increase blood pressure by up to 15/10 $\mathrm{mmHg}$. Several blood pressure values (at least two) should be obtained 1-2 minutes apart to ensure the measurement's accuracy (7). Monitoring blood pressure amplitude from 12 to 24 hours is the most accurate method for confirming the diagnosis.

\section{ASPECTS OF CARDIOVASCULAR RISK}

The concept of cardiovascular risk is based on the idea of mutual potentiation of risk factors in the same patient so that the cumulative risk is greater than the sum of its components. It is about the estimated risk of an acute coronary event or stroke in the hypertensive population over 5 or 10 years, extremely useful in assessing the optimal time for therapeutic intervention (8).

The term "additional risk" indicates the amount of risk added to the average risk through the presence of risk factors, subclinical organ damage, diabetes mellitus, clinically manifest cardiovascular or renal disease.

The terms "low", "medium", "high" and "very high" risk refer to the risk of fatal or non-fatal cardiovascular event at 10 years: $<15 \%, 15-20 \%, 20-30 \%$, respectively
$>30 \%$ according to Framingham criteria or cardiovascular death $<4 \%, 5-8 \%$, and $>8 \%$ according to SCORE criteria $(10,11)$.

\section{CARDIOVASCULAR RISK FACTORS IN FAMILY MEDICINE}

Between 1930 and 1950 there was a great increase in the analytical tools of epidemiology and statistics applied to clinical research. This has led to the creation of more appropriate models for the study of disease associations with a wide range of anthropometric, physiological or biochemical variations, environmental with other diseases and also with socio-economic data (12).

Ageing is simply a risk factor for cardiovascular disease, especially in men over 45 and women over 55 . With age, women's advantage of low cardiovascular risk is lost before menopause. One explanation is that most cardiovascular risk factors have a higher prevalence with age. At older ages, survival is lower for women with a history of myocardial infarction. The irreversible ageing process can be delayed by a balanced diet as well as by regular physical activity (13).

Sex is a significant risk factor: for men, there is a higher risk for heart disease than for pre-menopausal women. After the onset of menopause, a woman's risk is similar to that of a man because female hormones' protective effect (estrogens) disappears. If other risk factors (e.g. smoking) are associated, it increases women's risk significantly, even before menopause. The INTERHEART study showed that women experience the first acute myocardial infarction on average nine years later than men $(14,15)$.

Hereditary-collateral history of cardiovascular disease is considered a significant risk factor in first-degree male relatives before 55 and in females before the age of 65. Risk factors (including high blood pressure, diabetes and obesity) can also be "passed on" from one generation to the next. Some forms of cardiovascular disease are more common among certain racial and ethnic groups. Most patients with high blood pres-

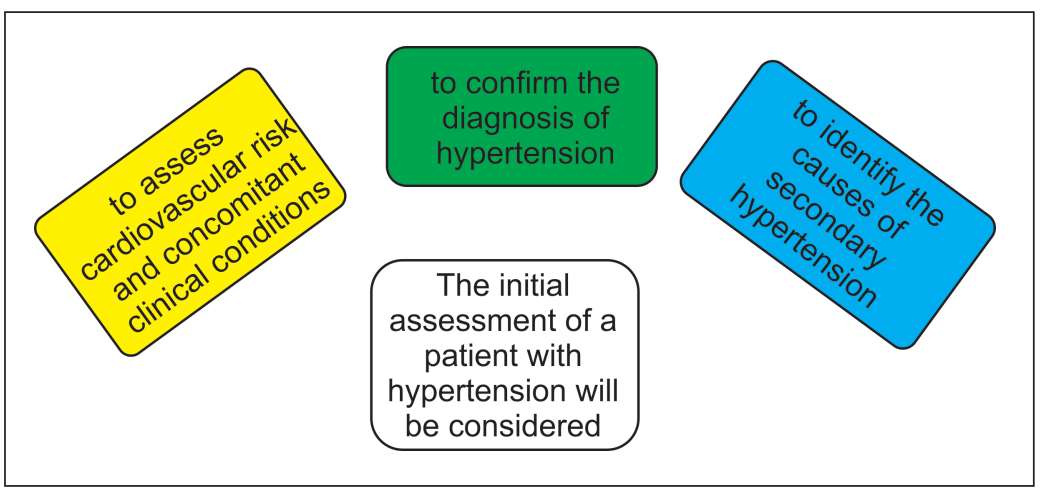

FIGURE 1. Initial evaluation 
TABLE 1. Stratification of cardiovascular risk in the patient with hypertension (9)

\begin{tabular}{|l|c|c|c|c|c|}
\hline Blood pressure (mmHg) & \multicolumn{5}{|l|}{ (mormally tall } \\
\hline $\begin{array}{l}\text { Other RF, subclinical } \\
\text { organ damage or } \\
\text { cardiovascular disease }\end{array}$ & $\begin{array}{c}\text { Normal } \\
\text { TAs 120-129 } \\
\text { Or TAd 80-84 }\end{array}$ & $\begin{array}{c}\text { HTA grade 1 } \\
\text { TAs 130-139 } \\
\text { Or TAd 85-89 }\end{array}$ & $\begin{array}{c}\text { TAs 140-159 or TAd } \\
90-99\end{array}$ & $\begin{array}{c}\text { HTA grade 2 TAs } \\
160-179 \text { or TAd100- } \\
109\end{array}$ & $\begin{array}{c}\text { HTA grade } 3 \\
\text { TAs } \geq 180 \text { or } \\
\text { TAd } \geq 110\end{array}$ \\
\hline No RF & $\begin{array}{c}\text { Moderate } \\
\text { Risk }\end{array}$ & $\begin{array}{c}\text { Moderate } \\
\text { Risk }\end{array}$ & Additional low risk & $\begin{array}{c}\text { Additional } \\
\text { moderate risk }\end{array}$ & Additional high risk \\
\hline One or two RFs & Additional low risk & Additional low risk & $\begin{array}{c}\text { Additional } \\
\text { Moderate risk }\end{array}$ & $\begin{array}{c}\text { Additional } \\
\text { moderate risk }\end{array}$ & $\begin{array}{c}\text { Additional } \\
\text { extremely high risk }\end{array}$ \\
\hline $\begin{array}{l}\text { Three or more RFs, } \\
\text { metabolic syndrome, } \\
\text { diabetes mellitus or } \\
\text { subclinical lesions }\end{array}$ & $\begin{array}{c}\text { Additional } \\
\text { moderate risk }\end{array}$ & Additional high risk & Additional high risk & Additional high risk & $\begin{array}{c}\text { Additional } \\
\text { extremely high risk }\end{array}$ \\
\hline $\begin{array}{l}\text { Stable cardiovascular } \\
\text { disease }\end{array}$ & $\begin{array}{l}\text { Additional } \\
\text { extremely high risk }\end{array}$ & $\begin{array}{l}\text { Additional } \\
\text { extremely high risk }\end{array}$ & $\begin{array}{c}\text { Additional } \\
\text { extremely high risk }\end{array}$ & $\begin{array}{c}\text { Additional } \\
\text { extremely high risk }\end{array}$ & $\begin{array}{c}\text { Additional } \\
\text { extremely high risk }\end{array}$ \\
\hline
\end{tabular}

RF-risk factor

sure are overweight. High blood pressure is about six times more common in obese subjects than in thin men and women (16).

Obesity itself is associated with changes in hemodynamics. An increase in oxygen demand caused by excess adipose tissue ( $\approx 1.5 \mathrm{ml} / \mathrm{kg}$ per minute) requires an increase in cardiac capacity. There is also a parallel increase in blood volume. Thus, obese people have an increase in blood volume, cerebral vascular volume and cardiac output. However, obese people with a higher than optimal increase in blood pressure (e.g., hypertension) have peripheral vascular resistance that is "inadequate" or increased. Therefore, although an increase in blood pressure may contribute to an increase in blood pressure in obese people, an abnormal increase in blood pressure depends primarily on the increase in peripheral vascular resistance $(17,18)$.

The assessment and recommendations for sedentary hypertensive patients are: physical activity can be beneficial for the prevention and treatment of hypertension and reducing cardiovascular risk and mortality. A meta-analysis of randomized controlled trials showed that aerobic endurance training reduces resting TAs and TAds by up to $3 / 2.4 \mathrm{mmHg}$ in total and even $6.9 / 4.9 \mathrm{~mm}$ in hypertensive participants (19). Even irregular activity and shorter duration of physical activity are associated with a $20 \%$ decrease in mortality in cohort studies, and this also applies to a measured physical condition (20).

Assessment and recommendations for hypertensive smoking patients are: while the smoking rate is de- clining in most European countries (where a smoking ban is effective), it is still common in many regions and groups. Studies using outpatient blood pressure monitored have shown that hypertensive, normotensive and untreated smokers have higher daily blood pressure values than non-smokers (21). In addition to the impact on blood pressure, smoking is a strong cardiovascular risk factor, and quitting smoking is probably the only way to prevent cardiovascular disease, including stroke, heart attack.

While moderate alcohol consumption may not be harmful, the shift from moderate to excessive consumption is associated with increased BP and an increased risk of stroke. The study on the prevention and treatment of hypertension (PATHS) investigated the effect of reducing BP. The intervention group had a higher reduction of $1.2 / 0.7 \mathrm{mmHg}$ of blood pressure than the control group at the end of the 6-month period (22). A large amount of alcohol can also lead to supraventricular arrhythmias.

\section{CONCLUSIONS}

High blood pressure is a global problem. The family doctor plays a significant role in prevention, early detection but also in monitoring the treatment. Current studies highlight the importance and need for family doctor involvement.

Conflict of interest: none declared Financial support: none declared

\section{REFERENCES}

1. Staessen JA, Fagard R, Thijs L, Celis $H$, Arabidze GG, Birkenhäger WH, Bulpitt CJ, de Leeuw PW, Dollery CT, Fletcher AE, et al.
Randomised double-blind comparison of placebo and active treatment for older patients with isolated systolic hypertension.
The Systolic Hypertension in Europe (Syst-Eur) Trial Investigators. Lancet. 1997 Sep 13;350(9080):757-64. 
2. MRC trial of treatment of mild hypertension: principal results. Medical Research Council Working Party. Br Med J (Clin Res Ed). 1985 Jul 13;291(6488):97-104.

3. 1999 World Health OrganizationInternational Society of Hypertension Guidelines for the Management of Hypertension. Guidelines Subcommittee. J Hypertens. 1999 Feb;17(2):151-83.

4. Chobanian AV, Bakris GL, Black HR, Cushman WC, Green LA, Izzo JL Jr, Jones DW, Materson BJ, Oparil S, Wright JT Jr, Roccella EJ; National Heart, Lung, and Blood Institute Joint National Committee on Prevention, Detection, Evaluation, and Treatment of High Blood Pressure; National High Blood Pressure Education Program Coordinating Committee. The Seventh Report of the Joint National Committee on Prevention, Detection, Evaluation, and Treatment of High Blood Pressure: the JNC 7 report. JAMA. 2003 May 21; 289(19):2560-72.

5. Dorobanțu M, Bădilă E, Ghiorghe RO, Olteanu M, Flondor P. Total cardiovascular risk estimation in Romania. Data from the SEPHAR study. Rom J Intern Med. 2008; 46(1):29-37.

6. Viera AJ. Screening for Hypertension and Lowering Blood Pressure for Prevention of Cardiovascular Disease Events. Med Clin North Am. 2017 Jul;101(4):701-712.

7. Vischer AS, Burkard T. Principles of Blood Pressure Measurement - Current Techniques, Office vs Ambulatory Blood Pressure Measurement. Adv Exp Med Biol. 2017;956:85-96

8. Bejan GC, Stănescu AMA, Ghilencea NL, Matei D. Analiza actuală a aspectelor terapeutice moderne în tratamentul HTA și al comorbiditătilor asociate. Ro Med J. 2018;65(2):102-107.

9. Mancia G, De Backer G, Dominiczak A, Cifkova R, Fagard R, Germano G, Grassi G,
Heagerty AM, Kjeldsen SE, Laurent S, Narkiewicz K, Ruilope L, et al; Management of Arterial Hypertension of the European Society of Hypertension; European Society of Cardiology. 2007 Guidelines for the Management of Arterial Hypertension: The Task Force for the Management of Arterial Hypertension of the European Society of Hypertension (ESH) and of the European Society of Cardiology (ESC). J Hypertens. 2007 Jun;25(6):1105-87.

10. Chobanian AV, Bakris GL, Black HR, Cushman WC, Green LA, Izzo JL Jr, Jones DW, Materson BJ, Oparil S, Wright JT Jr, Roccella EJ; Joint National Committee on Prevention, Detection, Evaluation, and Treatment of High Blood Pressure. National Heart, Lung, and Blood Institute; National High Blood Pressure Education Program Coordinating Committee. Seventh report of the Joint National Committee on Prevention, Detection, Evaluation, and Treatment of High Blood Pressure. Hypertension. 2003 Dec;42(6):1206-52.

11. Conroy RM, Pyörälä K, Fitzgerald AP, Sans S, Menotti A, De Backer G, De Bacquer D, Ducimetière $P$, Jousilahti $P$, Keil $U$, et al. SCORE project group. Estimation of ten-year risk of fatal cardiovascular disease in Europe: the SCORE project. Eur Heart J. 2003 Jun;24(11):987-1003.

12. Moriguchi E. New risk factors in clinical practice. Hypertension 2002; 5 (2): 63-66.

13. Bejan GC, Stănescu AMA, Ghilencea LN, lancu MA, Stefani C, Leica A Matei D. Este riscul cardiovascular global al pacienților hipertensivi superior sumei riscurilor individuale ale factorilor de risc implicați? Ro J Med Pract. 2019;14(1):57-61.

14. Anand SS, Islam S, Rosengren A, Franzosi MG, Steyn K, Yusufali AH, Keltai M, Diaz R, Rangarajan S, Yusuf S; INTERHEART Investigators. Risk factors for myocardial infarction in women and men: insights from the INTERHEART study. Eur Heart J. 2008 Apr;29(7):932-40.

15. Simionescu AA, Sabrina Stoica S, Hetea H. Coagularea intravasculara diseminata produsa la domiciliu in al treilea trimestru al sarcinii - doua cazuri clinice. Ginecologia.ro 2017;15(1):24-7.

16. Stamler R, Stamler J, Riedlinger WF, Algera $\mathrm{G}$, Roberts RH. Weight and blood pressure. Findings in hypertension screening of 1 million Americans. JAMA. 1978 Oct 6; 240(15):1607-10.

17. Reisin E. Weight reduction in the management of hypertension: epidemiologic and mechanistic evidence. Can J Physiol Pharmacol. 1986 Jun;64(6):818-24.

18. Stefani C, Miricescu D, Totan A, Greabu M, Stănescu AMA. Adipose tissue biomarkers and systemic health. Ro J Med Pract. 2019;14,4(69):366-370.

19. Cornelissen VA, Fagard RH. Effects of endurance training on blood pressure, blood pressure-regulating mechanisms, and cardiovascular risk factors. Hypertension. 2005 Oct;:46(4):667-75.

20. Rossi A, Dikareva A, Bacon SL, Daskalopoulou SS. The impact of physical activity on mortality in patients with high blood pressure: a systematic review. J Hypertens. 2012 Jul;30(7):1277-88.

21. Bang LE, Buttenschøn L, Kristensen KS, Svendsen TL. Do we undertreat hypertensive smokers? A comparison between smoking and non-smoking hypertensives. Blood Press Monit. 2000 Oct-Dec;5(5-6):271-4.

22. Cushman WC, Cutler JA, Hanna E, Bingham SF, Follmann D, Harford T, Dubbert $P$, Allender PS, Dufour M, Collins JF, et al. Prevention and Treatment of Hypertension Study (PATHS): effects of an alcohol treatment program on blood pressure. Arch Intern Med. 1998 Jun 8;158(11):1197-207. 